The proof of the system came with the Second World War. The agricultural officers of the local authorities were seconded as officials and advisers to the War Agricultural Committees, and it is not extravagant to claim that the tremendous advance made by British agriculture during the War was, in a large measure, due to the advice and help rendered to these committees by the local agricultural staffs.

In one sense they were too successful, for so impressed was the Ministry of Agriculture with their value as advisers-temporarily, through war-time regulations, under centralized control-that it decided, before the War ended, to set up a National Agricultural Advisory Service distinct from the County Agricultural Education Service. What had hitherto been one living-usually lively-organism was to be cut in two. This was done by the Agriculture (Miscellaneous Provisions) Act of 1944. It is doubtful whether any such Act could have been put on the statute book except in war-time, when the energies of those mainly concerned were concentrated on winning the battle for food production.

This new advisory service was planned to be set up, almost in toto, at a definite date, October 1, 1946, as a branch of the Civil Service with centralized control. Attractive salary scales were offered and those already engaged in agricultural education. before the War were given the right of application for transfer. The alternative was to remain with the local authority with no definite salary scales and with very hazy prospects for the future.

These county staffs provided almost the only source of recruitment for the new advisory service; inevitably it practically denuded the counties of most of their experienced personnel and was an extremely serious blow for agricultural education. This function was now transferred to the Ministry of Education, which had no experience in this field. In the future, 'advice' was somehow or other to be differentiated from 'education'. Further, instead of agricultural education being an important activity of the Ministry of Agriculture, it became a very minor sector of the vast front of the Ministry of Education.

It is not an exaggeration to say that most of those connected with agricultural education-whether or not they transferred to the advisory service-deeply deplored the new system. The late Prof. N. M. Comber, when president of the Agricultural Section of the British Association in 1949, admirably expressed this view in the following words : "Those now engaged in the advisory service have no official colleagueship with those who teach agricultural students in Universities and Colleges, and the teachers have no longer their foretime association with all that is going on in the farming of today. These teachers are, therefore, deprived of what has been the main source of their life-blood as teachers, and the suicidal character of the whole development can be seen by anyone who gives thought about the training of those to be appointed to the Advisory Service staff in the next generation or so. This separation of teaching and advisory work is, in my view, a major tragedy in the history of agricultural education".

It is not surprising, therefore, that, in November 1952, six years after the formation of the National Agricultural Advisory Service, the Minister of Agriculture and Fisheries set up a 'working party' "To review the relations between the agricultural education service of Local Authorities and the National Agricultural Advisory Service, and to make proposals for their more effective co-operation; to examine the need for an inspectorate of agricultural education; and to consider the future of the Joint Advisory Committee on Agricultural Education". Unfortunately, these terms of reference excluded from its inquiry "major structural changes in responsibility for either education or advice on agricultural subjects". The setting up of the "working party' disclosed the recognition of the existence of a 'dis-ease', but the 'working party' was strictly enjoined not to deal with the real cause of this disease, but merely to suggest measures for its alleviation.

Within such restricted terms of reference the working party in its report published in October last has made a number of minor, but useful, suggestions. Officers of the advisory and education service within each county are advised to meet together at least twice a year in order to organize better team-work and fuller collaboration in each other's activities. Similarly, the authorities responsible for the two sections of work are advised to have overlapping membership. A limited amount of secondment between the services is proposed in counties where staffs are large enough for it to be done. A small inspectorate of persons well qualified in agriculture or horticulture (but not members of the National Agricultural Advisory Service) is suggested. But the finding of greatest importance to the teaching side is that "suitably qualified L.I.A. staff are welcome to advise old students who are commercial producers, nor should they be debarred from advising other commercial producers if asked . . .". The final recommendation is that the Joint Advisory Committee on Agricultural Education, better known as the Loveday Committee, should lapse but be reconstituted when necessary for specific inquiries.

These results of a year's work by the twelve members of the Carrington working party are not very impressive; but in view of the terms of reference, it is difficult to think that the working party could have done better.

H. W. Gardner

\section{THE WORKERS' EDUCATIONAL ASSOCIATION}

THE Workers' Educational Association has recently produced two publications which indicate the way in which Great Britain's most prominent voluntary organization in adult education is adapting itself to meet the challenge of new times and new men. The first is a review of the Association's activities since the end of the Second World War, and the second the report of a working party set up to inquire into Trade Union education*.

Looking back to 1920 , the review shows how the Association has been tested in two world wars and emerged from both strengthened and revitalized. In 1913-14, there were 179 branches; 11,430 individual members; and there were 145 classes with 3,343 students. In 1919-20 there were 277 branches ; 20,703 individual members ; and there were 557 classes with 12,438 students. In 1938-39 there were 635 branches ; 28,652 individual members; and there were

* Trade Union Education : a Report from a Working Party set up by the Workers' Educational Association. Pp. 120. 4s. 6d. The Workers' Educational Association. A Review 1946-1952. Pp.
(London : Workers' Educational Association, 1953 and 1954.) 
3,306 classes with 58,735 students. In $1946-47$ there were 932 branches ; 45,320 individual members ; and there were 5,516 classes with 100,373 students. The scale of this increase is impressive; but its nature was very much influenced by the vast social changes brought about by the War itself. It was natural that the onset of war should hit the tutorial classes sharply; but these later recovered. Many new students, however, saw in the short terminal course a means of satisfying their immediate need for information and discussion.

After the War a new situation arose. The opportunities for the rapid expansion of adult education which the immediate post-war years seemed to offer did not materialize to the degree that had been hoped. The flow of new students and members from the Armed Forces was disappointingly small. Except in the high proportion of short courses, the class programme of districts did not reflect the possibilities of expansion which new grant regulations offered. There were also distracting;problems arising in districts from the effect of the Ministry of Education's new grant regulations on the work of university extramural departments and, to a less extent, of local education authorities ; a number of university extramural departments were anxious to avail themselves of their new power to extend their work rapidly in all directions and to enter fields hitherto reserved, by agreement, as well as by regulation, to the Workers' Educational Association. This introduced a new element into the Association-university relationships-and resolution of the difficulties to which it gave rise in districts was not easy.

Despite the Association's preoccupation with these matters, the number of classes and students continued to increase and, by $1948-49$, there were 6,380 classes with 111,351 students in them, the highest numbers so far attained. The number of manual workers in classes had steadily increased since 1946-47, and in 1948-49 the number of tutorial classes, 889, had almost reached the highest figures of pre-war years.

At the same time the total membership of the Association was declining. From a maximum of 45,320 in 1946-47, the number of individual members declined year by year until in $1951-52$ it stood at 34,628 . There is no simple way of accounting on a national basis for this decline, particularly in view of the corresponding increase in the number of branches and the consequent increase in new members needed to man them. The record suggests that exceptional local conditions have produced district losses in membership which when taken into the national total have exaggerated the actual average decline for the districts together. There are signs, however, that general losses are coming to an end and that a stable and even increasing membership may soon be achieved.

The report also describes the kind of classes which were taken by students. In 1938-39, 58 38 per cent of all classes were concerned with the social sciences : by $1945-46$ the proportion had risen to $63 \cdot 60$ per cent. Movement up and down in the two subsequent years was followed by steady increases to $55 \cdot 2$ per cent in 1951-52. Over the same period the proportion of classes in literature and the arts ranged from 25.8 per cent in 1944-45 sterdily upward with only one check to $32 \cdot 1$ per cent in 1950-51. Philosophy lost ground in 1944-45 and 1945-46 (3.5 per cent) but rose to $6 \cdot 9$ per cent in 1949-50, before declining to $6 \cdot 3$ per cent in 1951-52. Science lost ground in the immediate post-war years $(4 \cdot 2$ per cent in 1945-46), but increased slowly year by year to reach $6 \cdot 7$ per cent in 1951-52.

It is much more difficult to present the facts about the occupational background from which students have been recruited. Every year since 1946-47 the proportion of manual workers has decreased slightly from a maximum of 22 per cent in 1946-47 to $18 \cdot 89$ per cent in 1950-51. Those occupied with domestic and home duties increased steadily after the War but declined to 20 per cent in 1951. The proportion of clerks, draughtsmen and travellers declined steadily from 17 per cent in $1946-47$ to 14.9 per cent in 1950-51. The proportion of teachers has increased from an average of 10 per cent from 1944-48 to $12 \cdot 1$ per cent in $1950-51$.

Besides accounts of the Association's relationships with Trade Unions and its responsibilities in the national educational system as a whole, the review also deals with the relation of the Association to similar organizations in other countries, as well as the prominent part played by the Association in the formation of the International Federation of Workers' Educational Associations after the War.

The working party, which was set up under the chairmanship of the Right Hon. A. Creech Jones, was concerned with educational work for trade unionists in relation to the Trade Union movement. Its report shows that, in recent years, discussions of Trade Union education have taken a new turn. The development of nationalization, a renewed interest in what is loosely called 'workers' control', the growth of joint consultation and joint production committees, have led to an increasing interest in management studies and the administration of industry. The working party suggests that the real purpose of trade education in this field is to give active and representative trade unionists a closer understanding and a clearer grasp of the functions and problems of industrial administration. This will enable them to contribute more positively to the solution of the problems they are interested in, rather than merely pressing their claims regardless of their wider implications. This is particularly important where modern 'scientific management' techniques such as time- and motion-study and job evaluation are involved.

Among the subjects of study suggested by various Workers' Educational Association Trade Union advisory committees to the working party were the following: courses for branch officials, for shop stewards, and general educational course ; courses in public expression, reporting-back, chairmanship, and secretarial practice, technical subjects such as incentive pryment schemes, time- and motion-study, job evaluation, improvements in productivity ; the techniques of negotiation, joint consultation, the development of labour relations, human factors in industry ; Trade Union policy-making, wages structure and wages policy, the Whitley system; business and industrial organization, statistics, the use of balance sheets; Trade Union law and industrial law; the Industrial Injuries Act; the history and organiza. tion of particular Unions; the new functions of Trade Unions and trade unionism in other countries.

A number of these advisory committees recommended that there should be special provision for the training of full-time Trade Union officers, while others felt that there is a need for educating young trade unionists in industrial relations, and in their 
obligations to industry and to the Trade Union movement and its aims.

It was recognized that the demand for Trade Union education was very difficult to stimulate, and this was widely felt to be the fundamental obstacle to expansion. There was general agreement that full advantage was not being taken of existing facilities. In considering the structure of Trade Union education it should be stated that the British Trade Union movement lacks a systematic structure and a fully authoritative and financially well-equipped co-ordinating body. It cannot do more than work gradually towards a complete and systematic union education. The individual Union will be for some time yet the unit of authority, of finance, and of educational policy, and the growth of Trade Union education and its co-ordination will depend on the relations of the educational bodies concerned with the Trade Unions the requirements of which have to be satisfied. The phases of Trade Union education in which the need for further development is obvious are: informal educational activities at the branch Trade Union meeting; training in the skills required in active work for the Trade Union movement; and the education of branch officers and lay representatives in practical and policy aspects of Trade Union action. A beginning has already been made in these directions, and further development depends on finance, supply of tutors, the use of appropriate methods, and the effective organization of the demand.

Experience already gathered in Trade Union classes shows the necessity for providing preliminary training in the 'tools of study' for some students selected for intensive courses. This has its impact on the general conduct of Trade Union business through the frustration which results when people are inadequately equipped to shape and express their opinions. The working party recommends that experiments should be carried out into ways of covering more adequately the legitimate demands for training in self-expression, meeting procedure, case preparation, and reporting, without encouraging glibness in public speaking or a tiresome obsession with procedure. Branch officers and lay representatives should also be trained in the practical skills involved in Trade Union action. These include secretarial practice, chairmanship, public speaking and the making of reports, committee and meeting procedure, the handling of documentary material and dealing with complaints and grievances.

The development of specific educational classes for trade unionists is beset by difficulties arising out of the Ministry of Education's grant regulations for adult education classes. These classes can be arranged by local education authorities on a grant-earning basis; they cannot be arranged by the Workers' Educational Association. What is needed is freedom for the Association to undertake development experimentally in various types of Trade Union education, and for this purpose to be able to disregard, within reason, the limits imposed by adult education regulations. It is important in Trade Union education to build on the immediate interests and experience of the students. Different types of approach will be required, and experience outside liberal adult education must be taken fully into account.

The supply of tutors for Trade Union education may easily become a bottleneck limiting or distorting development as the demand begins to grow. It is not known whether there are unused teaching resources which could be brought into action if an enlarged demand for Union education were experienced, and whether the supply could be increased by the provision of training courses. In developing the less academic types of Trade Union education it may be possible to draw on trained teachers who are not in universities or grammar schools, on Trade Union officers, and on others who have special knowledge or aptitude.

There is not a large number of university or Workers' Educational Association tutors who, in the post-war period, have made a special study of Trade Union questions, and only a minority will have had any industrial experience. If tutors are to do successful work in Trade Union education they should become familiar with the activities and policies of Trade Unions, and be able to gain the confidence of the people with whom they will work.

The working party also considered the part played by other organizations in Trade Union education, like the National Council of Labour Colleges and Ruskin College, and suggested that greater co-ordination would be achieved by setting up a central Trade Union education bureau, the function of which should be to collect and disseminate information about activities and experiments in the field of Trade Union education, to make available books, pamphlets and other educational material found to be needed, and, generally, to stimulate and to guide interest in Trade Union education in a variety of ways and to provide assistance to individuals and groups engaged in it.

T. H. Hawkins

\section{OBITUARIES}

\section{Prof. F. C. Chalklin}

Prof. F. C. Chalklin was born in 1902 and received his school education at Judd School, Tonbridge. He entered King's College, London, with a leaving exhibition and graduated in 1923 with honours in physics. For the four succeeding years he carried out research work on soft X-rays with Prof. (now Sir) Owen Richardson, obtaining the $\mathrm{Ph} . \mathrm{D}$. degree in 1926. He was appointed assistant lecturer in physics in the University of Sheffield in 1927 and three years later became a lecturer at University College, London. In 1939, two years after obtaining the D.Sc. degree, Chalklin was appointed a reader in the University of London. During the Second World War he was in charge of that part of the Physics Department of University College which was evacuated to Aberystwyth. Soon after the War, in 1946, he was appointed professor of physics in the University of New Zealand at Christchurch. It was on a visit back to Britain that the tragic air disaster at Singapore terminated a devoted and successful career.

Chalklin's experimental work was mainly concerned with the spectroscopy of soft X-rays, a subject in which he was a world authority. He built several grating spectrographs, with which he obtained valuable results. The greater part of his research work was carried out single-handed, or with the collaboration of his wife, Miss L. P. Davies, whom he met in the research laboratory at King's College, London. He had thrown himself with vigour into the task of building up a research school in Christchurch and his recent publications showed that much progress to this end had already been made. 